\title{
Variant GDF9 mRNA is likely not the main cause of larger litter size in Iranian Lori-Bakhtyari, Shal, Ghezel, and Afshari sheep breeds
}

\author{
Shahin Eghbalsaied ${ }^{1,2}$, Farzad Rashidi Khorasgani ${ }^{1}$, Hamid-Reza Amini ${ }^{1}$, Majid Farahi ${ }^{1}$, \\ Maryam Davari ${ }^{2}$, Ahmad Pirali ${ }^{2}$, Sheila Pourali ${ }^{1}$, Mahmood Vatankhah ${ }^{3}$, Mahmud Rostami ${ }^{1}$, and \\ Hadi Atashi ${ }^{4}$ \\ ${ }^{1}$ Transgenesis Center of Excellence, Isfahan (Khorasgan) branch, Islamic Azad University, Isfahan, Iran \\ ${ }^{2}$ Department of Animal Science, Faculty of Agriculture, Isfahan (Khorasgan) branch, Islamic Azad University, \\ Isfahan, Iran \\ ${ }^{3}$ Department of Animal Science, Chaharmahal va Bakhtiary Agricultural and Natural Resources Research and \\ Education Center, AREEO, Shahrekord, Iran \\ ${ }^{4}$ Department of Animal Science, Shiraz University, Shiraz, Iran \\ Correspondence to: Shahin Eghbalsaied (shahin.eghbal@khuisf.ac.ir)
}

Received: 21 January 2017 - Revised: 6 April 2017 - Accepted: 15 April 2017 - Published: 17 May 2017

\begin{abstract}
This study was carried out to screen the GDF9 gene and evaluate the polymorphism effect on litter size of four Iranian sheep breeds using the PCR-RFLP and PCR-SSCP methods. First, sequencing of the GDF9 gene in 16 twin-birth, 4 triplet-birth, and 2 infertile ewes showed that, in addition to G2, G3, G4, G5, and G6 mutations that have been previously reported in other breeds, a new G0 mutation, called C25T, exists in the GDF9 sequence of 1 out of 22 ewes and causes L9F substitution in the signal peptide region. None of the triplet-birth or infertile ewes carried G1, G4, G7, FecGE, G8, or FecGT mutations. In the second experiment, a large dataset was used: 605 individuals including 496 ewes (145 Afshari, 54 Shal, 126 Ghezel, and 171 Lori-Bakhtyari sheep), and 109 rams (26 Afshari, 23 Shal, 10 Ghezel, and 50 Lori-Bakhtyari sheep. There were no sheep carrying the G7, G8, or Thoka mutations. Among all 109 rams that were used in this study, none of them were homozygous for the G1 mutation. Moreover, abundance of heterozygote rams $(\mathrm{G} 1 / \mathrm{G}+$ ) varied from 0.0 (Afshari) to $28.6 \%$ (Lori-Bakhtyari and Ghezel). The highest and the lowest frequencies of the G4 mutation were 30.6 and $3.0 \%$ in Shal and Afshari breeds, respectively. Moreover, G4 abundance varied from 0.0 to $42.3 \%$, from 3.0 to 26.9, and from 3.0 to $30.6 \%$ in rams, ewes, and overall, respectively. There was a significant difference in the abundance of G1 and G4 mutations between breeds. However, neither the G1 nor the G4 mutation was associated with litter size in Afshari, Ghezel, Lori-Bakhtyari, or Shal sheep breeds. In conclusion, the results of this study showed that GDF9 G1 and G4 mutations are not the reason for higher litter size in Iranian sheep. Moreover, the GDF9 G0 and G6 mutations do not cause triplet births or infertility in Iranian ewes. Therefore, it is unlikely that variant GDF9 mRNA induces larger litter size or infertility in Iranian ewes.
\end{abstract}




\section{Introduction}

In mammals, ovulation rate and fetus survival are decisive managerial attributes. It has been well-documented that single-nucleotide polymorphism (SNP) in a narrow assembly of genes, including growth differentiation factor 9 (GDF9), bone morphogenetic protein 15 (BMP15), bone morphogenetic protein receptor $1(B M P R I B)$, and leptin, can increase ovulation rate, multiple-lamb births, and fecundity in sheep (Souza et al., 2001; Wilson et al., 2001; Hanrahan et al., 2004; Juengel et al., 2004, 2015). These genes belong to the transforming growth factor $\beta$ (TGF $\beta$ ) superfamily, which consists of 50 physiologically important macromolecules that regulate fertility and growth attributes, as well as cellular differentiation processes (Dong et al., 1996; Yan et al., 2001).

The importance of GDF9 protein on oocyte and follicular growth and function was defined by Dong et al. (1996) and McGrath et al. (1995), and afterward the ovine GDF9 gene was mapped on chromosome 5 (Sadighi et al., 2002). Even though the GDF9 gene is expressed in the oocyte of cumulusoocyte complex (COC) (McGrath et al., 1995; Laitinen et al., 1998), its higher expression in the cellular layers around the antral follicles has recently been identified as key during the follicular phase of ewes (Foroughinia et al., 2017). As summarized in Table 1, following the first publication on discovering eight mutations, designated as $\mathrm{G} 1$ to $\mathrm{G} 8$, in the GDF9 gene of Belclare and Cambridge breeds (Hanrahan et al., 2004), other mutations were discovered in Thoka (FecGT) (Nicol et al., 2009), Han (FecG-Han) (Chu et al., 2011), and various Spanish (FecGE) (Silva et al., 2011) sheep breeds. Among these mutations, G2, G3, G5 (Chu et al., 2011), and G-C (Nicol et al., 2009) are ineffective mutations without amino acid codon alteration. However, G1, G4, G6 (Chu et al., 2011), and FecGH (López-Ramírez et al., 2014) modify the GDF9 propeptide, while G7, G8 (Chu et al., 2011), GD (Juengel et al., 2011), and FecGT (Chu et al., 2011) mutations cause variation in the mature peptide. Two of these SNPs, GDF9 G8 and FecGT, show over-dominant inheritance for ovulation rate and twin birth but an infertility event at a homozygous mutant state (Hanrahan et al., 2004; Nicol et al., 2009). Moreover, the FecGE (Silva et al., 2011), G1 (Barzegari et al., 2010; Javanmard et al., 2011), G4 (Eghbalsaied et al., 2012, 2014), and G7 (Våge et al., 2013) mutations were reported as ovulation inducers without showing sterility. It has been proven that the origin of FecGH in Belclare and Cambridge sheep is the highly prolific Lleyn breed (Mullen et al., 2013). However, a large proportion of rams and high-fecundity ewes from the Lleyn breed and other highly prolific ewe breeds that had records of triplet births did not carry the known significant mutations (Mullen et al., 2013). This might indicate that other mutations in the detected major genes or other genes from the transforming growth family could affect the ovulation rate in ewes.
Mutation in the GDF9 gene has been detected in Iranian sheep breeds, i.e. Zel (Ghaderi et al., 2010; Javanmard et al., 2011; Nassiry et al., 2006), Lori-Bakhtyari, Sangesari (Hafezian, 2011), Moghani (Barzegari et al., 2010), Ghezel (Akbarpour et al., 2008; Barzegari et al., 2010; Eghbalsaied et al., 2014), Shal (Ghaffari et al., 2009), Kurdi, Arabi (Ghaderi et al., 2010), Baluchi (Moradband et al., 2011), Afshari (Eghbalsaied et al., 2012), Mehraban (Zamani et al., 2015), and Lori (Zamani et al., 2015). However, all of these SNPs moderately modify the signal peptide or GDF9 propeptide. Conversely, neither the major known mutations that can change the mature peptide nor the ewe sterility that is the main side effect of ewe homozygosity for these major SNPs have been observed in Iranian ewes (Akbarpour et al., 2008; Eghbalsaied et al., 2012, 2014; Ghaffari et al., 2009; Moradband et al., 2011; Nejhad and Ahmadi, 2012). Even though the GDF9 G1 mutation was not considered as an effective mutation for sheep prolificacy by Hanrahan et al. (2004), it was suggested as an effective source for inducing twin birth in Iranian Ghezel and Moghani breeds (Barzegari et al., 2010; Javanmard et al., 2011). However, further research on the Mehraban breed (Abdoli et al., 2013) could not prove the significant effect of the GDF9 G1 SNP on Iranian sheep flocks. Also, the effect of other mutations, such as GDF9 G4 (Eghbalsaied et al., 2012) and GDF9 G6 (Khodabakhshzadeh et al., 2016), needs to be evaluated in highly fertile Iranian ewes. Therefor, evaluation of GDF9 mutations in twin births of Iranian ewes remains to be explored in a large dataset of Iranian sheep breeds. The aim of this study was to screen and analyse GDF9 polymorphism effects on twin births of Iranian sheep breeds, including LoriBakhtyari, Shal, Ghezel, and Afshari.

\section{Material and methods}

\subsection{Experiment 1}

Screening of the GDF9 gene in a sample of twin-birth ewes

To search for possible mutations that are segregated in ewes with larger litter size sheep, a random sample of 16 ewes with twin births, 4 ewes with triplet births, and 2 ewes with infertility were selected from Shal, Ghezel, Afshari, and LoriBakhtyari breeds. The blood was immediately mixed with $50 \mathrm{mM}$ EDTA, transported to the laboratory, and stored at $-20^{\circ} \mathrm{C}$ for further analysis. Genomic DNA was extracted from the whole blood using the standard phenol-chloroform method. The quantity and quality of extracted DNA was measured by spectrophotometer and agarose gel electrophoresis, respectively. Based on the Ovis aries breed Texel chromosome 5, Oar_v3.1, whole genome shotgun sequence on the National Center for Biotechnology Information (NCBI) website, three primer pairs were designed by Oligo6 software to cover the 5' UTR and complete sequence of exon 1, com- 
Table 1. A summary of known mutations that have been detected in the GDF9 gene of sheep species around the world.

\begin{tabular}{lllll}
\hline Reference & Protein segment & Amino acid change & DNA base change & SNP \\
\hline This paper & Signal peptide & L9F & C25T & G0 \\
Hanrahan et al. (2004) & Propeptide & R87H & G260A & G1 \\
Hanrahan et al. (2004) & Propeptide & Unchanged V & C471T & G2 \\
Hanrahan et al. (2004) & Propeptide & Unchanged L & G477A & G3 \\
Hanrahan et al. (2004) & Propeptide & K241E & A721G & G4 \\
Chu et al. (2011) & Propeptide & Q243H & G729T & FecG-Han \\
Nicol et al. (2009) & Propeptide & Unchanged R & G750A & G-C \\
Juengel et al. (2011) & Mature peptide & R286S & G858T & G-D \\
Hanrahan et al. (2004) & Mature peptide & Unchanged E & A978G & G5 \\
Hanrahan et al. (2004) & Mature peptide & V332I & G994A & G6 \\
Silva et al. (2011) & Mature peptide & F345C & T1034G & FecGE \\
Hanrahan et al. (2004) & Mature peptide & V371M & G1111A & G7 \\
Hanrahan et al. (2004) & Mature peptide & S395F & C1184T & G8 (FecGH) \\
Nicol et al. (2009) & Mature peptide & S427R & A1279C & FecGT \\
\hline
\end{tabular}

Table 2. Distribution of collected samples from ewes and rams belonging to Iranian sheep breeds.

\begin{tabular}{llllllll}
\hline \multirow{2}{*}{ Breed } & \multicolumn{9}{c}{ Ewe } & Ram & Location & Total number \\
\cline { 2 - 6 } & \multicolumn{3}{c}{ Triplets Twins Single Infertile } & & \\
\hline Shal & 3 & 30 & 19 & 2 & 23 & Pir Yusefiyan (Bu'in Zahra) & 77 \\
Ghezel & - & 10 & 30 & - & 10 & Miandoab Research Center & 136 \\
& - & 52 & 34 & - & - & Semmeneh Rud (Boukan) & \\
\hline Afshari & - & 70 & 30 & - & 6 & Khatoon Abad (Isfahan) & 171 \\
& 1 & 110 & 60 & - & 20 & Isfahan & \\
\hline Lori-Bakhtiyari & 1 & 50 & Shahrekord, Lordegan, Farsan & 221 \\
\hline Total number & 4 & 272 & 218 & 2 & 109 & Iran & 605 \\
\hline
\end{tabular}

plete sequence of exon 2, a part of exon 2, and the 3' UTR of the ovine GDF9 gene (Table 2). Polymerase chain reactions (PCR) were carried out in $25 \mu \mathrm{L}$ volume, included $1 \mathrm{X}$ Buffer, $250 \mathrm{mM}$ dNTP, $5 \mathrm{mM} \mathrm{MgCl}_{2}, 5 \mu \mathrm{M}$ primers, 50-100 ng template DNA, and 1 IU Taq DNA Polymerase (SinaClon, Iran). Except for the annealing temperature, PCR conditions were similar for all reactions, with initial denaturation at $94{ }^{\circ} \mathrm{C}$ for $4 \mathrm{~min}, 35$ cycles of denaturation at $94^{\circ} \mathrm{C}$ for $30 \mathrm{~s}$, annealing at $55-60^{\circ} \mathrm{C}$ for $30 \mathrm{~s}$, and extension at $72{ }^{\circ} \mathrm{C}$ for $30 \mathrm{~s}$, and finished by a final extension at $72^{\circ} \mathrm{C}$ for $4 \mathrm{~min}$. The PCR amplicons of the 16 ewes were sent for sequencing (Bio Basic Inc., Canada) and aligned with the Ovis aries GDF9 mRNA; sequence ID is $\mathrm{gb}|\mathrm{AF} 078545.2| \mathrm{AF} 078545$.

\subsection{Experiment 2}

\subsubsection{DNA samples and PCR reaction}

In this experiment, the detected mutations in Experiment 1 were assessed using twin births of four main breeds of Iranian sheep. Five millilitres of a blood sample was collected from the jugular vein of 605 sheep, including 77, 136, 171, and 221 Shal, Ghezel, Afshari, and Lori-Bakhtyari breeds, respectively (Table 3 ). Among these animals, four tripletbirth and two infertile ewes were also included. Five primer pairs were used for detection of G0, G1, G4, G6, and G8 mutations in GDF9 gene (Table 2) (Polley et al., 2010). The PCR conditions were similar to Experiment 1.

\subsubsection{Restriction fragment length polymorphism (RFLP)}

For detection of G1 and G8 mutations, $1 \mu \mathrm{g}$ of the PCR product was digested with $H h a \mathrm{I}$ and $D d e \mathrm{I}$ restriction enzyme, respectively (Takara Bio Inc., Japan), at $37^{\circ} \mathrm{C}$ for $1 \mathrm{~h}$. Then the digested solution was loaded on a $1.5 \%$ agarose gel containing GelRed (Biotium, USA) and screened using gel documentation (Uvitech, UK) merchandiser.

\subsubsection{Single-strand conformation polymorphism (SSCP)}

Detection of the G0, G4, G6, and G8 mutations as well as the G0 mutation that was newly detected in Experiment 1, was carried out using the SSCP procedure (Orita et al., 1989). In summary, $5 \mu \mathrm{L}$ of the PCR product was transferred to an Ep- 
Table 3. Primer pairs for mutation detection in the GDF9 gene of Iranian sheep based on NCBI accession reference AF078545.

\begin{tabular}{lllll}
\hline Coverage region & Primer sequence $5^{\prime} \rightarrow 3^{\prime}$ & $\begin{array}{l}\text { Amplicon } \\
\text { length }(\mathrm{bp})\end{array}$ & Tm (C) & Reference \\
\hline G0 & $\begin{array}{l}\text { AGAACTGCAATTCCACTCAAGATT } \\
\text { GCCTTCCTCATGGCCAAATG }\end{array}$ & 161 & 59 & Current paper \\
\hline G1 & $\begin{array}{l}\text { TCTTCTTCCCTCCACCCATTAACCAATC } \\
\text { GCCTGGCTCTGTTTTCCTATTAGCCTTG }\end{array}$ & 396 & 61 & Polley et al. (2010) \\
\hline G4 & $\begin{array}{l}\text { CCTGCTGGGTTAGAAGGGTT } \\
\text { TTCCCCACGTTTGTTGCTTTC }\end{array}$ & 195 & 60 & Current paper \\
\hline G6 & $\begin{array}{l}\text { GATGCTAACCTCCAGCAGCA } \\
\text { TGCCCTCATGGGTTGATGTAG }\end{array}$ & 91 & 60 & Current paper \\
\hline G8 & $\begin{array}{l}\text { GGATTGTGGCCCCACACAAATACAACCC } \\
\text { CATCAGGCTCGATGGCCAAAACACTCAA }\end{array}$ & 198 & 55 & Polley et al. (2009) \\
\hline $5^{\prime}$ UTR + exon 1 & $\begin{array}{l}\text { GAATGAATAGGGTGTTGTCAGC } \\
\text { TTAAGGCCATTAAATCTCTTCTAGC }\end{array}$ & 809 & 59 & Current paper \\
\hline Exon 2 & CCCCACCAAAGCTATTCTGA & 757 & 61 & Current paper \\
\hline $3^{\prime}$ CACCCTCAGCAGCTTCTTCT & TTACATGTGCGGAAGACCAG & 859 & 60 & Current paper \\
\hline
\end{tabular}

pendorf tube and mixed with $7.0 \mu \mathrm{L}$ of a gel loading solution that contained $99 \%$ formamide, $0.05 \%$ bromophenol blue, $0.05 \%$ xylene cyanol, and $20 \mathrm{mM}$ EDTA $(\mathrm{pH}=8.0)$. The mixture was incubated and denatured at $96^{\circ} \mathrm{C}$ for $10 \mathrm{~min}$, chilled on ice for $5 \mathrm{~min}$, and loaded onto $12 \%$ neutral polyacrylamide gels. Electrophoresis was performed at 130 volt for $18 \mathrm{~h}$ at $10-12{ }^{\circ} \mathrm{C}$. Afterward, the single-strand DNA was made visible using silver staining (Bassam et al., 1991).

\section{Statistical analysis}

The following generalized linear model (GLM) was used for evaluation of the detected polymorphisms in ewe twin births.

Twinbirth $=$ mean + breed $+\mathrm{G} 1+\mathrm{G} 4+\mathrm{E}$,

where mean, breed, G1, G4, and E were the average of twin births in the whole population. Breed and genotype of ewes for the G1 and G4 mutations were fixed effects, and unknown residual effects were random effect. The statistical analysis was carried out using SAS 9.2 software. Mean of litter size was compared between genotype categories using the least significant difference test $(p$ value $<0.05)$. Genetic analysis was carried out using the Popgene 1.32 software (Francis and Yang, 2000) and genotypic and allelic frequencies were compared using the Chi-square test $(p$ value $<0.05)$.

\section{Results}

\subsection{Detection of mutations converting L9F (G0) and V332I (G6)}

In the first part of this study, the pair-wise alignment results of the sequenced fragments and the Ovis aries GDF9 mRNA were used to determine possible mutations in the surveyed samples from twin-birth, triplet-birth, and infertile ewes. As depicted in Fig. 1, results showed that along with the G1 mutation, five previously reported mutations, namely the GDF9 G2, G3, G4, G5, and G6 (Hanrahan et al., 2004), are present in highly prolific Iranian ewes with 3.1 (1 out of 16), 3.1 ( 1 out of 16), 7.1 (3 out of 21), 30.0 (6 out of 20 ), and $30.0 \%$ (6 out of 20) frequency, respectively. Furthermore, we detected a new mutation, designated as G0, in one out of the 22 sequenced samples. This mutation exists in exon 1 of the GDF9 gene, causing C25T to shift and subsequently L9F to convert into the amino acid polypeptide. This amino acid change occurs in signal peptide of GDF9 protein (Senta et al., 2009) and is completely conserved among sheep [NP_001136360.2], goats [NP_001272637.1], cattle [NP_777106.1], dogs [NP_001161485.1], wild boar [NP_001001909.1], humans [NP_001275754.1], and mice [NP_032136.2] (Fig. 2). The GDF9 G6 mutation was the only detected mutation that affected the active polypeptide sequence. We did not detect G7, G8, FecGT, and FecGE mutations in the evaluated samples. 

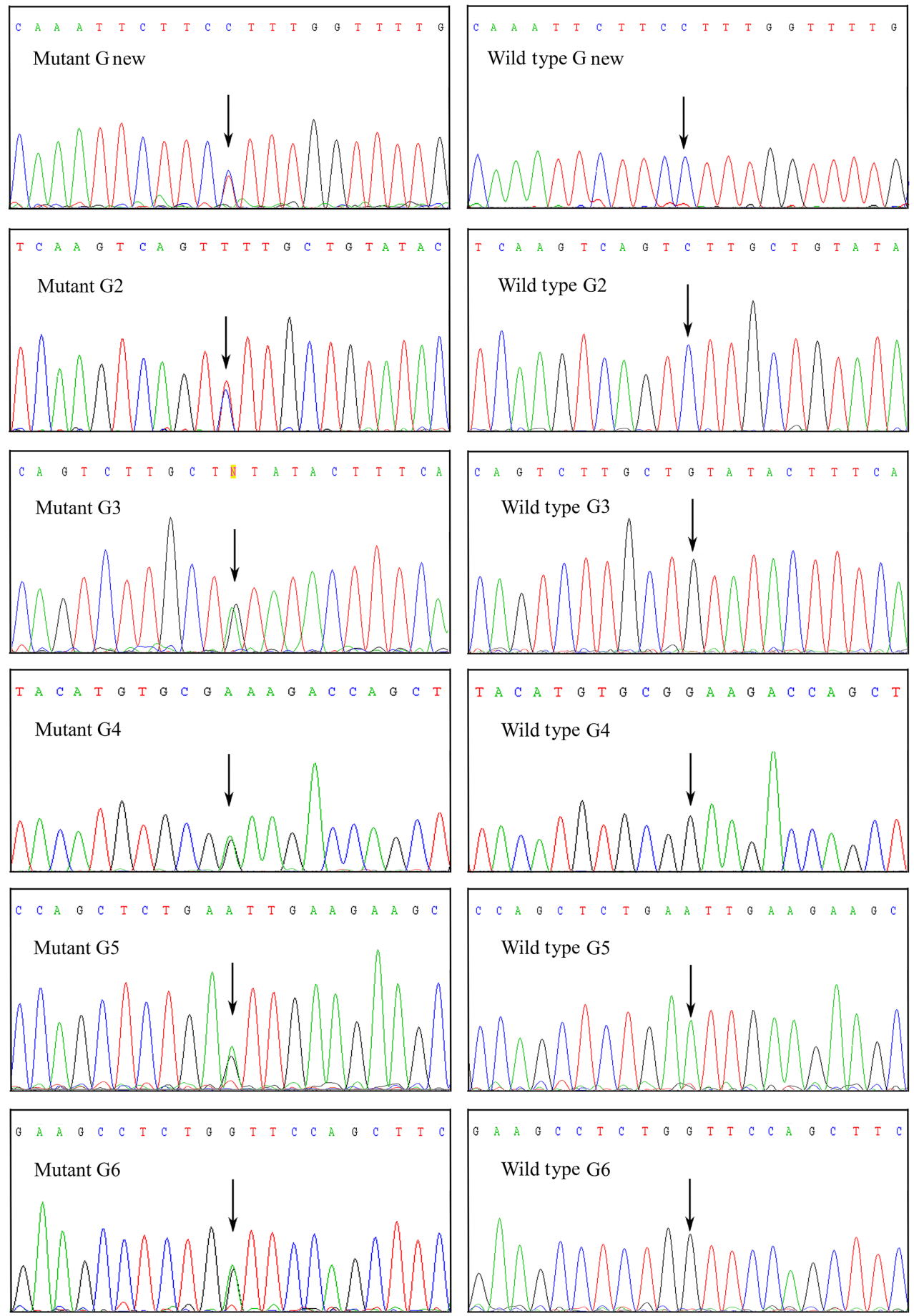

Figure 1. Graphical representation of detected mutations in GDF9 DNA of Iranian twin-birth ewes compared to sequence ID $\mathrm{gb}|\mathrm{AF} 078545.2|$ AF078545. G0 (C25T) is the newly detected mutation; G2-G6 were previously defined by Hanrahan et al. (2004) .

\subsection{G1 and G4 SNPs were unimportant for twin births in Iranian ewes}

In this study, we collected a large sample size of sheep from four main breeds in Iran, including Afshari, Ghezel, LoriBakhtyari, and Shal. Four primer pairs were used to amplify
DNA sequences that cover the G0, G1, G4, and G6 mutations. We used a SSCP approach for discriminating the possible alleles in the studied population. However, amplicons that contain G0 or G6 mutations were not distinguishable using the SSCP method, although we included the animals that 


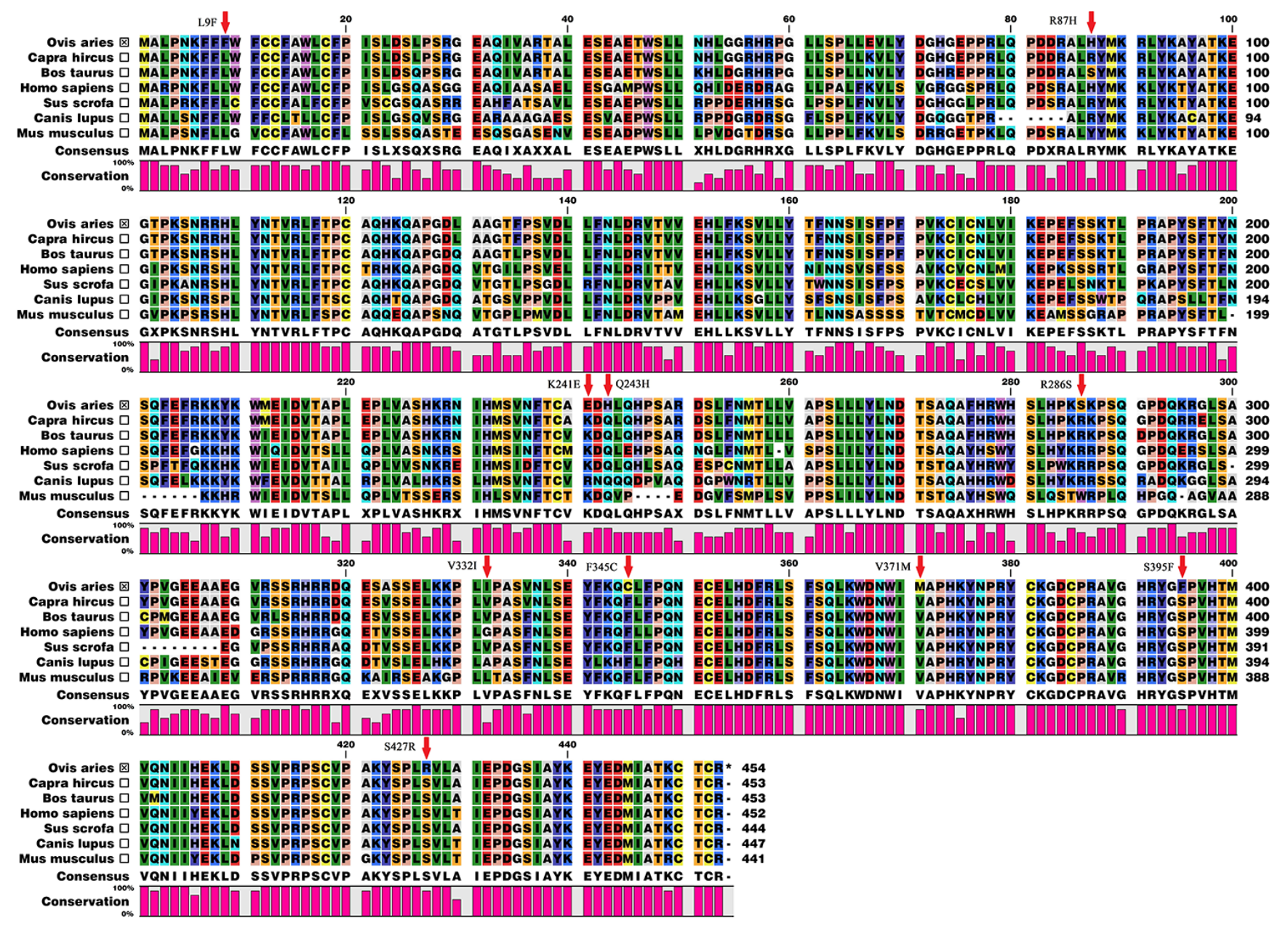

Figure 2. Multiple alignment of GDF9 propeptide sequence among sheep [NP_001136360.2], goats [NP_001272637.1], cattle [NP_777106.1], dogs [NP_001161485.1], wild boar [NP_001001909.1], humans [NP_001275754.1], and mice [NP_032136.2]. The amino acid changes due to the detected GDF9 mutations in sheep are illustrated by arrows.

were previously verified as heterozygous genotypes for these mutations.

Results of this study for genotypic and allelic frequencies for the G1 mutation (G260A) in Iranian sheep breeds are presented in Table 4. Among all 109 rams that were used in this study, none of them were homozygous for the G1 mutation. Moreover, abundance of heterozygote rams $(\mathrm{G} 1 / \mathrm{G}+)$ varied from 0.0 (Afshari) to $28.6 \%$ (Lori-Bakhtyari and Ghezel). Analysis of pooled data from ewes and rams indicated that there was a high difference in G1 allelic frequency as well as genotypic distribution among the four mentioned breeds ( $p$ value $=0.046$ ). Although this allele was not detected in the Lori-Bakhtyari breed, its abundance was $14.0 \%$ in the Ghezel breed. Our results based on the large dataset comprised of Afshari, Ghezel, Lori-Bakhtyari, and Shal breeds could not detect any significant effect of the G1 mutation on the litter size of ewes (Fig. 3) ( $p$ value $=0.991$ ). In addition, neither the two infertile ewes nor the four triplet-birth ewes carried the G1 mutation.
The highest and the lowest frequencies of the G4 mutation were detected in the Shal and Afshari breeds, respectively (Table 5). G4 mutation frequency varied from 0.0 to $42.3 \%$, from 3.0 to 26.9 , and from 3.0 to $30.6 \%$ in rams, ewes, and overall, respectively. There was a significant difference in the abundance of the G4 mutation between breeds ( $p$ value $=0.003$ ). However, no homozygote $\mathrm{G} 4 / \mathrm{G} 4$ was observed in ewes and rams of the Afshari breed. Moreover, using this large dataset in the current study showed that the G4 mutation did not have a significant effect on ewe twin births (Fig. 4) $(p$ value $=0.864)$.

\section{Discussion}

A high number of mutations were reported by Hanrahan et al. (2004) in Belclare and Cambridge sheep. The GDF9 G1 mutation was previously detected in the Iranian Ghezel, Moghani, and Afshari breeds (Abdoli et al., 2016; Eghbalsaied et al., 2014; Noshahr and Rafat, 2014). Additionally, 
Table 4. Allelic and genotypic frequencies of the GDF9 G1 mutation (G260A) in Iranian Shal, Ghezel, Afshari, and Lori-Bakhtyari sheep breeds.

\begin{tabular}{lllll|ll}
\hline \multirow{2}{*}{ Breed } & Sex & \multicolumn{3}{c|}{ Genotype frequency $(\%)$} & \multicolumn{2}{l}{ Allelic frequency (\%) } \\
\cline { 3 - 7 } & & G+/G+ & G+/G1 & G1/G1 & G+ & G1 \\
\hline \multirow{3}{*}{ Shal } & Male & 93.7 & 6.3 & 0.0 & 96.9 & 3.1 \\
& Female & 81.8 & 9.1 & 9.1 & 86.4 & 13.7 \\
\multirow{3}{*}{ Ghezel } & Overall & 85.7 & 8.2 & 6.1 & 89.8 & 10.2 \\
& Male & 71.4 & 28.6 & 0.0 & 85.7 & 14.3 \\
& Female & 74.0 & 24.0 & 2.0 & 86.0 & 14.0 \\
\multirow{3}{*}{ Afshari } & Overall & 73.7 & 24.6 & 1.7 & 86.0 & 14.0 \\
& Male & 100.0 & 0.0 & 0.0 & 100.0 & 0.0 \\
\multirow{3}{*}{ Lori-Bakhtyari } & Female & 81.4 & 14.0 & 4.6 & 88.4 & 11.6 \\
& Overall & 85.4 & 11.0 & 3.6 & 90.9 & 9.1 \\
& Male & 71.4 & 28.6 & 0.0 & 85.7 & 14.3 \\
& Female & 89.3 & 10.7 & 0.0 & 94.7 & 5.4 \\
Total & Overall & 88.2 & 11.8 & 0.0 & 94.1 & 5.9 \\
\hline
\end{tabular}

Table 5. Allelic and genotypic frequencies of the GDF9 G4 mutation (G721A) in Iranian Shal, Ghezel, Afshari, and Lori-Bakhtiari sheep breeds.

\begin{tabular}{lllll|ll}
\hline \multirow{2}{*}{ Breed } & Sex & \multicolumn{3}{c|}{ Genotype frequency (\%) } & Allelic frequency (\%) \\
\cline { 3 - 7 } & & G+/G+ & G+/G4 & G4/G4 & G+ & G4 \\
\hline \multirow{3}{*}{ Shal } & Male & 30.8 & 53.8 & 15.4 & 57.7 & 42.3 \\
& Female & 51.2 & 43.9 & 4.9 & 73.2 & 26.9 \\
\multirow{3}{*}{ Ghezel } & Overall & 46.3 & 46.3 & 7.4 & 69.5 & 30.6 \\
& Male & 75.0 & 12.5 & 12.5 & 81.3 & 18.8 \\
& Female & 62.5 & 30.0 & 7.5 & 77.5 & 22.5 \\
Afshari & Overall & 64.6 & 27.1 & 8.3 & 78.2 & 21.9 \\
& Male & 0.0 & 0.0 & 0.0 & 0.0 & 0.0 \\
& Female & 94.1 & 5.9 & 0.0 & 97.1 & 3.0 \\
Lori-Bakhtyari & Overall & 94.1 & 5.9 & 0.0 & 97.1 & 3.0 \\
& Male & 66.6 & 16.7 & 16.7 & 75.0 & 25.1 \\
& Female & 61.4 & 28.4 & 10.2 & 75.6 & 24.4 \\
& Overall & 61.7 & 27.6 & 10.7 & 75.5 & 24.5 \\
\hline \multirow{2}{*}{ Total } & & 63.5 & 28.7 & 7.8 & 77.9 & 22.2 \\
\hline
\end{tabular}

the presence of GDF9 G2, G3, and G4 SNPs was confirmed in the Iranian Afshari breed (Eghbalsaied et al., 2012). Moreover, existence of G5 and G6 mutations in the GDF9 gene of Iranian ewes has also been recently reported (Khodabakhshzadeh et al., 2016). The GDF9 G1 and G4 mutations convert arginine to histidine and glutamic acid to lysine in the pre-peptide but not the matured polypeptide. The G6 mutation converts valine to isoleucine in the active GDF9 protein. Both valine and isoleucine are classified into hydrophobic side-chain amino acids. It should be noteworthy that all significant mutations in the ovine GDF9 gene, including G7, G8, FecGE, and FecGT, occur in a completely conserved region of the protein. Results of a recent publication indicated that unlike the suggestion by Hanrahan et al. (2004), the G7 missense mutation that causes valine to convert to methio- nine (both have a hydrophobic side-chain amino acid) does affect the twin birth rate in Norwegian white sheep (Våge et al., 2013). The existence of the G0 mutation, C25T, has recently been reported by the Ensembl website using the next generation sequencing data from Iranian (IROV) and Moroccan Ovis aries sheep (MOOV) with 2.5 and $0.6 \%$ frequency, respectively (rs605683468). In agreement with this only sequencing report, the frequency of this mutation was $2.3 \%$ with no homozygote genotype in the sequenced samples. We need to consider the point that only 1 out of 16 twin-birth ewes carried this mutation, while $94 \%$ of twin-birth ewes, all four triplet-birth ewes, and two infertile ewes did not carry this mutation. Therefore, the C25T or G0 mutation is not likely the reason for twin births in Iranian ewes, although valine is conserved among sheep, goats, cattle and wild boar. 

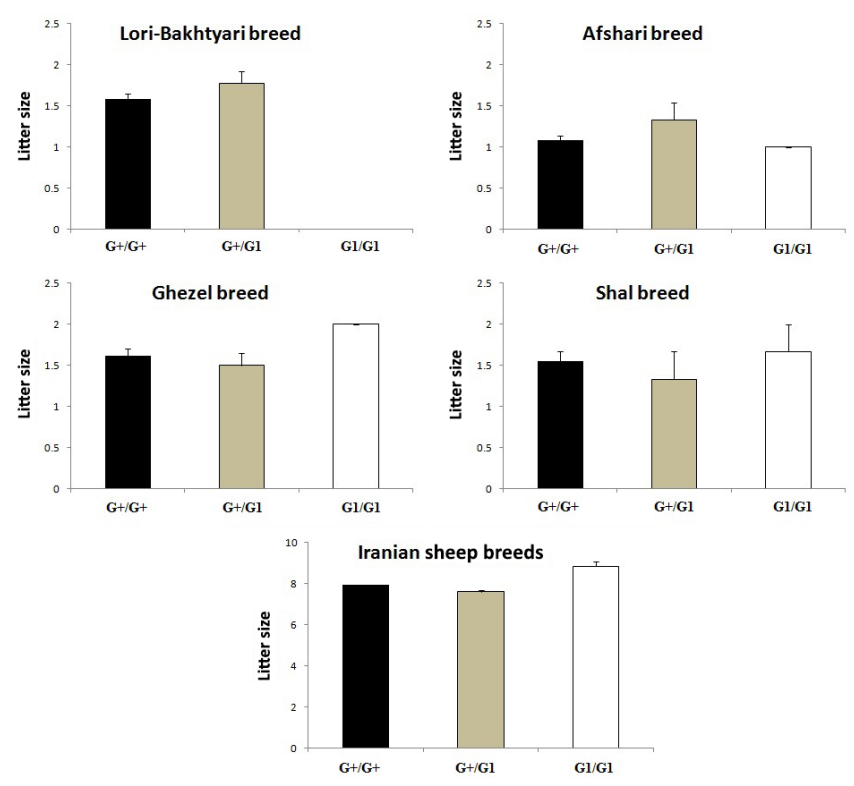

Figure 3. Litter size of Iranian ewes carrying the G1 mutation in the GDF9 gene.

However, the G6 mutation was observed in 6 out of 14 sequenced samples from twin-birth records, all in a heterozygote state. However, neither the ewes with triplet births nor the infertile ewes carried this mutation. Although the SSCP technique could not differentiate the mutation in this study, we cannot rule out the possible partial effect of this mutation in litter size of Iranian ewes. Moreover, the G1 mutation alters a non-conserved region, even in ruminants, and the G4 mutation also supports conservancy rather than decreasing it. Moreover, both mutations occur in the pre-peptide region. Thus, these mutations might be less likely to be effective in altering GDF9 activity. In the sequenced sample, we could not detect any homozygous genotype for these mutations, although, for example, the moderate frequency of G6 mutations indicated that we could expect around $4 \%$ homozygosity for GDF9 G6. This may be due to the fact that such mutations are segregated at very low frequency and thus they are highly affected by the sampling method. Therefore, using a larger sample size will be required for evaluation of the allelic and genotypic frequencies as well as the corresponding effect of these SNPs. Similarly, further mutations are expected to be detected by increasing the number of highly fertile ewes.

In the second phase of this study, we collected a large sample size of Iranian sheep. We tried to genotype the animals for G0, G1, G4, and G6 mutations. However, the SSCP approach could not detect either G0 or G6 mutations. This could be due to insensitivity of the SSCP procedure in detecting these mutations. There are several parameters such as type of filtering matrix, type of additive, wall coating, temperature, and voltage that can significantly alter the SSCP
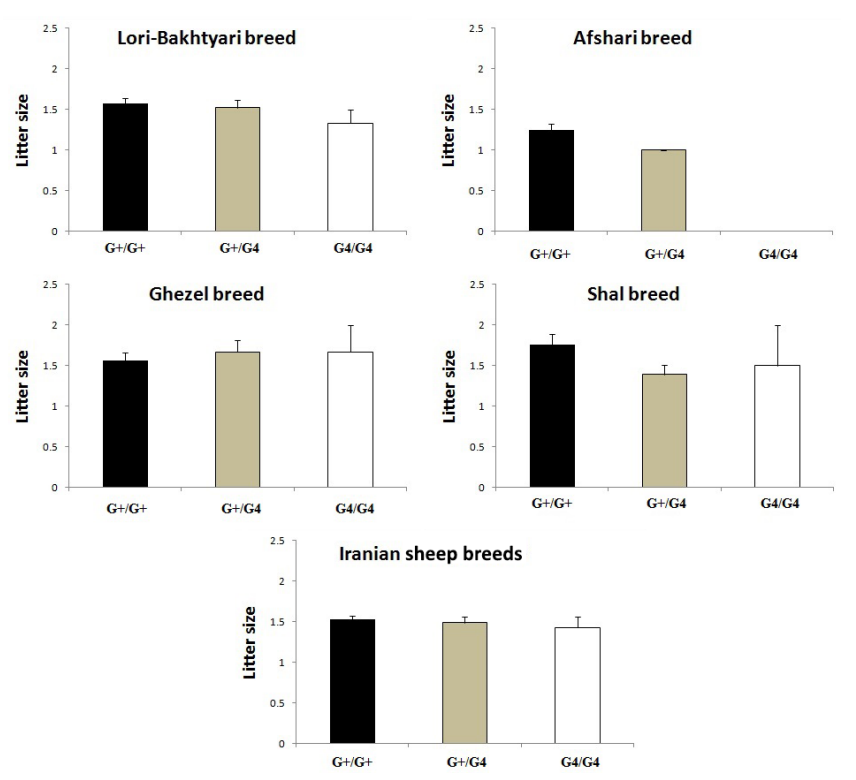

Figure 4. Litter size of Iranian ewes carrying the G4 mutation in the $G D F 9$ gene.

banding pattern (for review see Sinville and Soper, 2007). Insensitivity or low sensitivity of SSCP compared to other SNP detection technologies was also reported (Low et al., 2000). Although we used a standard range of parameters for SSCP optimization (Eghbalsaied et al., 2016; Khodabakhshzadeh et al., 2016), implementing this technology was not helpful for distinguishing possible mutations in these amplicons.

Using the RFLP and SSCP methods, the G1 and G4 mutations were distinguished, respectively. A considerable difference was observed between genotypic frequencies in different breeds so that this allele was not detected in the LoriBakhtyari breed, while it was present in $14.0 \%$ of the Ghezel breed. Also, none of the sires in this study were homozygous for the G1 mutation. In the literature, the frequency of the G1 mutation in Iranian breeds has been reported as follows: $8.7-15.7 \%$ in the Ghezel breed (Barzegari et al., 2010; Eghbalsaied et al., 2014), 2.7-24.0\% in the Afshari breed (Eghbalsaied et al., 2014; Javanmard et al., 2011), 0.0\% in the Shal breed (Eghbalsaied et al., 2014), $15.7 \%$ in the Moghani breed (Barzegari et al., 2010), 18.0-23.0\% in the Baluchi breed (Javanmard et al., 2011; Moradband et al., 2011), $19.8 \%$ in the Sangsari breed (Hafezian, 2011), $22.5 \%$ in the Makui breed (Javanmard et al., 2011), and 18.0-40.6\% in the Mehraban breed (Abdoli et al., 2013; Javanmard et al., 2011). These genetic polymorphisms in Iranian sheep corresponded to a $24.0 \%$ frequency in the Chios and Karagouniko breeds in Greece (Liandris et al., 2012), and 5.0-20.0\% in the Sal'skaya and Romanov breeds in Russia (Kolosov Yu et al., 2015).

The importance of the G1 mutation on ewe prolificacy is controversial in the literature. Although it has been suggested as an important mutation that increases twin births in the 
Ghezel and Moghani breeds in Iran (Barzegari et al., 2010) as well as the Chios and Karagouniko breeds in Greece (Liandris et al., 2012), an adverse effect of this mutation on litter size was reported in Iranian Baluchi sheep (Moradband et al., 2011). Interestingly, an over-dominant effect of this gene was also reported for litter size of Iranian Mehraban, Afshari, Baluchi, and Makui breeds (Javanmard et al., 2011), while no important effect of the G1 mutation on litter size was reported in Mehraban ewes (Abdoli et al., 2013). Differences in the sampling size and the power of the SSCP vs. RFLP techniques may be the reason for these large discrepancies in the literature. Our results with a large sample size showed that the distribution of genotypic frequencies among singlebirth and twin-birth ewes was not different in all the studied breeds. This clearly showed that the G1 mutation is not responsible for infertility or multiple-lamb births in Iranian ewes. It was suggested that G1 mutation (G260A) causes $\mathrm{R} 87 \mathrm{H}$ changes in the amino acid chain, leading to replaced arginine instead of histidine in the pre-peptide region of the GDF9 protein and therefore it has no effect on ewe litter size (Hanrahan et al., 2004). The results of our study support the hypothesis of Hanrahan et al. (2004) and the findings of Abdoli et al. (2013) for Iranian sheep. In addition, lack of homozygous mutant rams in all four breeds in the current study indicated that this mutation does not favour twin births in Iranian ewes under natural or artificial selection.

The other mutation that was screened for in the current study on Iranian sheep breeds was (G721A) G4 (Hanrahan et al., 2004). The G4 mutation frequency varied significantly between breeds, so that it was estimated at $3.0 \%$ in the Shal breed and $30.6 \%$ in the Afshari breed. It is evident that the G4 mutation is present in the Iranian Afshari, Shal, and Sangsari breeds. The frequency of this mutation was estimated at $7.9 \%$ in the Afshari breed (Eghbalsaied et al., 2014); 6.25\% in Shal (Eghbalsaied et al., 2014); $10.0 \%$ in the Ghezel breed (Eghbalsaied et al., 2014); $19.0 \%$ in Greek sheep breeds (Liandris et al., 2012); 44.8 and $3.8 \%$ in the Belclare and Cambridge breeds of Ireland, respectively (Hanrahan et al., 2004); and 95.0 and $80.0 \%$ in the Sal'skaya and Romanov sheep breeds of Russia (Kolosov Yu et al., 2015).

The GDF9 G4 mutation was not significantly important for ewe twin births. The effect of the G4 mutation on twin births in Greek ewes was also not significant (Liandris et al., 2012). There are limited publications that address the frequency and the importance of the G4 mutation. There was one ewe, which was homozygous for G4 mutation, with a very high number of antral follicles (Eghbalsaied et al., 2012). The G4 mutation (G721A) causes glutamine-241lysine conversion, which takes place in the GDF9 pre-peptide and is unlikely to affect GDF9 functional activity (Hanrahan et al., 2004). More importantly, none of the four ewes with triplet births or the two infertile ewes carried the G1 or G4 mutations.
Screening the GDF9, BMP15, and BMPRIB genes in Davisdale sheep indicated that several mutations in $G D F 9$ and BMP15 segregate in these breeds. However, none of these mutations were responsible for higher ovulation rate and litter size in these breeds (Juengel et al., 2011). Instead, mutation in the leptin receptor gene was significantly associated with delayed onset of puberty and a decrease in ovulation rate and litter size in these breeds (Haldar et al., 2014). Therefore, it is possible that mutations in other genes, such as BMP15, BMPR1B (Eghbalsaied et al., 2016), leptin, or leptin receptor, are responsible for higher antral follicle count, ovulation rate, and litter size in Iranian sheep breeds. A recent study showed that in addition to the bone morphogenetic protein signaling pathway, expression of genes involved in estrogen and AMPK synthesis can be important factors in antral follicle count in ewes (Foroughinia et al., 2017). Therefore, more comprehensive studies are required to determine effective genetic mechanism controlling ewe twin births in Iranian sheep breeds.

\section{Conclusion}

In this study, a new mutation was detected in the early prepeptide region of the GDF9 gene. In addition, the $\mathrm{G} 1$ and G4 mutations were highly variable among different breeds so that they were not observed in homozygote mutants in rams of some breeds. Moreover, neither the G1 nor the G4 mutation had an effect on ewe litter size. This clearly indicated that the selected rams in these flocks were neither naturally nor artificially selected for these mutations. In addition, the G8 mutation was not observed in these sheep breeds. None of triplet-birth or infertile ewes carried the G0, G1, G4, G6, G8, and Thoka SNPs. In conclusion, the results of this study suggest that the GDF9 $\mathrm{G} 1$ and $\mathrm{G} 4$ mutations are not the reason for higher litter size or fecundity in Iranian sheep. Moreover, neither GDF9 G0 nor G6 mutations cause triplet births or infertility in Iranian ewes. Therefore, it is unlikely that variant GDF9 SNPs, which currently segregate in Iranian ewes, induce larger litter size or infertility.

Data availability. The data (sequencing data and SSCP results) used in this article can be found in the Supplement.

\section{The Supplement related to this article is available online at doi:10.5194/aab-60-119-2017-supplement.}

Competing interests. The authors declare that they have no conflict of interest. 
Acknowledgements. The authors would like to thank Alan McNeilly for his invaluable collaboration in conducting this project. This project was supported by the Iran National Science Foundation (INSF) through grant no. 90002710.

Edited by: S. Maak

Reviewed by: P. Zamani and M. Mohammadabadi

\section{References}

Abdoli, R., Zamani, P., Deljou, A., and Rezvan, H.: Association of BMPR-1B and GDF9 genes polymorphisms and secondary protein structure changes with reproduction traits in Mehraban ewes, Gene, 524, 296-303, 2013.

Abdoli, R., Zamani, P., Mirhoseini, S., Ghavi Hossein-Zadeh, N., and Nadri, S.: A review on prolificacy genes in sheep, Reprod. Domest. Anim., 51, 631-637, 2016.

Akbarpour, M., Houshmand, M., Ghorashi, A., and Hayatgheybi, H.: Screening for FecGH mutation of growth differentiation factor 9 gene in Iranian Ghezel sheep population, Cell j (Yakhteh), 2, 139-144, 2008.

Barzegari, A., Atashpaz, S., Ghabili, K., Nemati, Z., Rustaei, M., and Azarbaijani, R.: Polymorphisms in GDF9 and BMP15 associated with fertility and ovulation rate in Moghani and Ghezel sheep in Iran, Reprod. Domest. Anim., 45, 666-669, 2010.

Bassam, B. J., Caetano-Anollés, G., and Gresshoff, P. M.: Fast and sensitive silver staining of DNA in polyacrylamide gels, Anal. Biochem., 196, 80-83, 1991.

Chu, M., Wu, Z., Feng, T., Cao, G., Fang, L., Di, R., Huang, D., Li, X., and Li, N.: Polymorphism of GDF9 gene and its association with litter size in goats, Vet. Res. Commun., 35, 329-336, 2011.

Dong, J., Albertini, D. F., Nishimori, K., Kumar, T. R., Lu, N., and Matzuk, M. M.: Growth differentiation factor-9 is required during early ovarian folliculogenesis, Nature, 383, 531-535, 1996.

Eghbalsaied, S., Ghaedi, K., Shahmoradi, S., Pirestani, A., Amini, H., Saiedi, T., Nicol, L., and McNeilly, A.: Presence of SNPs in GDF9 mRNA of Iranian Afshari sheep, Int. J. Fertil. Steril., 5, 225-230, 2012.

Eghbalsaied, S., Amini, H., Shahmoradi, S., and Farahi, M.: Simultaneous Presence of G1 and G4 Mutations in Growth Differentiation Factor 9 Gene of Iranian Sheep, Iranian Journal of Applied Animal Science, 4, 781-785, 2014.

Eghbalsaied, S., Amini, H.-R., Rashidi Khorasgani, F., Velayati, D., and Pourali, S.: Detection of new mutations in exon 8 of BMPR1B gene in Iranian Lori-Bakhtyari, Shal, Ghezel, and Afshari sheep breeds, Journal of Agricultural Biotechnology, 8, 1-14, 2016.

Foroughinia, G., Fazileh, A., and Eghbalsaied, S.: Expression of genes involved in BMP and estrogen signaling and AMPK production can be important factors affecting total number of antral follicles in ewes, Theriogenology, 91, 36-43, 2017.

Francis, C. and Yang, R.: Popgene version 1.32, 2000.

Ghaderi, A., Nasiri, M. B., Mirzadeh, K., Fayazi, J., and Sadr, A.: Identification of the GDF9 mutation in two sheep breeds by using polymerase chain reaction-restriction fragment length polymorphism (PCR-RFLP) technique, African Journal of Biotechnology, 9, 8020-8022, 2010.

Ghaffari, M., Nejati-Javaremi, A., and Rahimi-Mianji, G.: Lack of polymorphism in the oocyte derived growth factor (GDF9) gene in the Shal breed of sheep, S. Afr. J. Anim. Sci., 39, 355-360, 2009.

Hafezian, S. H.: Genetic polymorphism BMP15 and GDF9 genes in Sangsari sheep of Iran, International Journal of Genetics and Molecular Biology, 3, 31-34, 2011.

Haldar, A., French, M. C., Brauning, R., Edwards, S. J., O'Connell, A. R., Farquhar, P. A., Davis, G. H., Johnstone, P. D., and Juengel, J. L.: Single-nucleotide polymorphisms in the LEPR gene are associated with divergent phenotypes for age at onset of puberty in Davisdale ewes, Biol. Reprod., 90, 1-7, 2014.

Hanrahan, J. P., Gregan, S. M., Mulsant, P., Mullen, M., Davis, G. H., Powell, R., and Galloway, S. M.: Mutations in the genes for oocyte-derived growth factors GDF9 and BMP15 are associated with both increased ovulation rate and sterility in Cambridge and Belclare sheep (Ovis aries), Biol. Reprod., 70, 900-909, 2004.

Javanmard, A., Azadzadeh, N., and Esmailizadeh, A. K.: Mutations in bone morphogenetic protein 15 and growth differentiation factor 9 genes are associated with increased litter size in fat-tailed sheep breeds, Vet. Res. Commun., 35, 157-167, 2011.

Juengel, J., Bodensteiner, K., Heath, D., Hudson, N., Moeller, C., Smith, P., Galloway, S., Davis, G., Sawyer, H., and McNatty, K.: Physiology of GDF9 and BMP15 signalling molecules, Anim. Reprod. Sci., 82, 447-460, 2004.

Juengel, J. L., O'Connell, A. R., French, M. C., Proctor, L. E., Wheeler, R., Farquhar, P. A., Dodds, K. G., Galloway, S. M., Johnstone, P. D., and Davis, G. H.: Identification of a line of sheep carrying a putative autosomal gene increasing ovulation rate in sheep that does not appear to interact with mutations in the transforming growth factor beta superfamily, Biol. Reprod., 85, 113-120, 2011.

Juengel, J. L., French, M. C., O’Connell, A. R., Edwards, S. J., Haldar, A., Brauning, R., Farquhar, P. A., Dodds, K. G., Galloway, S. M., and Johnstone, P. D.: Mutations in the leptin receptor gene associated with delayed onset of puberty are also associated with decreased ovulation and lambing rates in prolific Davisdale sheep, Reprod. Fert. Develop., 1318-1325, 2015.

Khodabakhshzadeh, R., Mohammadabadi, M., Esmailizadeh, A., Moradi Shahrebabak, H., Bordbar, F., and Ansari Namin, S.: Identification of point mutations in exon 2 of GDF9 gene in Kermani sheep, Pol. J. Vet. Sci., 19, 281-289, 2016.

Kolosov Yu, A., Getmantseva, L., Shirockova, N., Klimenko, A., Bakoev, S. Y., Usatov, A., Kolosov, A. Y., Bakoev, N., and Leonova, M.: Polymorphism of the GDF9 Gene in Russian Sheep Breeds, Journal of Cytology \& Histology, 6, 1-4, 2015.

Laitinen, M., Vuojolainen, K., Jaatinen, R., Ketola, I., Aaltonen, J., Lehtonen, E., Heikinheimo, M., and Ritvos, O.: A novel growth differentiation factor-9 (GDF-9) related factor is co-expressed with GDF-9 in mouse oocytes during folliculogenesis, Mech. Dev., 78, 135-140, 1998.

Liandris, E., Kominakis, A., Andreadou, M., Kapeoldassi, K., Chadio, S., Tsiligianni, T., Gazouli, M., and Ikonomopoulos, I.: Associations between single nucleotide polymorphisms of GDF9 and BMP15 genes and litter size in two dairy sheep breeds of Greece, Small Ruminant Res., 107, 16-21, 2012.

López-Ramírez, R. B., Magaña-Sevilla, H. F., Zamora-Bustillos, R., Ramón-Ugalde, J. P., and González-Mendoza, D.: Analysis of the 3'end regions of the GDF9 and BMPR1B genes in Blackbelly sheep from Yucatán, Mexico, Ciencia e investigación agraria: re- 
vista latinoamericana de ciencias de la agricultura, 41, 123-128, 2014.

Low, E. O., Jones, A. M., Gibbins, J. R., and Walker, D. M.: Analysis of the amplification refractory mutation allele-specific polymerase chain reaction system for sensitive and specific detection of p53 mutations in DNA, J. Pathol., 190, 512-515, 2000.

McGrath, S. A., Esquela, A. F., and Lee, S.-J.: Oocyte-specific expression of growth/differentiation factor-9, Mol. Endocrinol., 9, 131-136, 1995.

Moradband, F., Rahimi, G., and Gholizadeh, M.: Association of polymorphisms in fecundity genes of GDF9, BMP15 and BMP15-1B with litter size in Iranian Baluchi sheep, Asian Austral. J. Anim., 24, 1179-1183, 2011.

Mullen, M. P., Hanrahan, J. P., Howard, D. J., and Powell, R.: Investigation of Prolific Sheep from UK and Ireland for Evidence on Origin of the Mutations in BMP15 (FecXG, FecXB) and GDF9 (FecGH) in Belclare and Cambridge Sheep, PloS one, 8, e53172, doi:10.1371/journal.pone.0053172, 2013.

Nassiry, M. R., Tahmoorespour, M., Javadmanesh, A., Soltani, M., and Foroutani Far, S.: Calpastatin polymorphism and its association with daily gain in Kurdi sheep, Iranian Journal of Biotechnology, 4, 188-192, 2006.

Nejhad, R. K. and Ahmadi, A. K.: Genetic Polymorphism in GDF9 and FecB Genes in Dalagh Sheep Breed of Iran, J. Anim. Vet. Adv., 11, 766-768, 2012.

Nicol, L., Bishop, S. C., Pong-Wong, R., Bendixen, C., Holm, L.E., Rhind, S. M., and McNeilly, A. S.: Homozygosity for a single base-pair mutation in the oocyte-specific GDF9 gene results in sterility in Thoka sheep, Reproduction, 138, 921-933, 2009.

Noshahr, F. A. and Rafat, A.: Genetic Polymorphism of GDF9 Gene in Iranian Moghani Sheep Breed, Iranian Journal of Applied Animal Science, 4, 887-890, 2014.

Orita, M., Iwahana, H., Kanazawa, H., Hayashi, K., and Sekiya, T.: Detection of polymorphisms of human DNA by gel electrophoresis as single-strand conformation polymorphisms, P. Natl. Acad. Sci. USA, 86, 2766-2770, 1989.

Polley, S., De, S., Batabyal, S., Kaushik, R., Yadav, P., Arora, J. S., Chattopadhyay, S., Pan, S., Brahma, B., and Datta, T. K.: Polymorphism of fecundity genes (BMPR1B, BMP15 and GDF9) in the Indian prolific Black Bengal goat, Small Ruminant Res., 85, 122-129, 2009.

Polley, S., De, S., Brahma, B., Mukherjee, A., Vinesh, P., Batabyal, S., Arora, J. S., Pan, S., Samanta, A. K., and Datta, T. K.: Polymorphism of BMPR1B, BMP15 and GDF9 fecundity genes in prolific Garole sheep, Trop. Anim. Health Prod., 42, 985-993, 2010 .
Sadighi, M., Bodensteiner, K., Beattie, A., and Galloway, S.: Genetic mapping of ovine growth differentiation factor 9 (GDF9) to sheep chromosome 5, Anim. Genet., 33, 244-245, 2002.

Senta, H., Park, H., Bergeron, E., Drevelle, O., Fong, D., Leblanc, E., Cabana, F., Roux, S., Grenier, G., and Faucheux, N.: Cell responses to bone morphogenetic proteins and peptides derived from them: biomedical applications and limitations, Cytokine Growth Factor Rev., 20, 213-222, 2009.

Silva, B., Castro, E., Souza, C., Paiva, S., Sartori, R., Franco, M., Azevedo, H., Silva, T., Vieira, A., and Neves, J.: A new polymorphism in the Growth and Differentiation Factor 9 (GDF9) gene is associated with increased ovulation rate and prolificacy in homozygous sheep, Anim. Genet., 42, 89-92, 2011.

Sinville, R. and Soper, S. A.: High resolution DNA separations using microchip electrophoresis, J. Sep. Sci., 30, 1714-1728, 2007.

Souza, C., MacDougall, C., Campbell, B., McNeilly, A., and Baird, D.: The Booroola $(\mathrm{FecB})$ phenotype is associated with a mutation in the bone morphogenetic receptor type $1 \mathrm{~B}$ (BMPR1B) gene, J. Endocrinol., 169, R1-R6, 2001.

Våge, D. I., Husdal, M., Kent, M. P., Klemetsdal, G., and Boman, I. A.: A missense mutation in growth differentiation factor 9 (GDF9) is strongly associated with litter size in sheep, BMC genetics, 14, doi:10.1186/1471-2156-14-1, 2013.

Wilson, T., Wu, X.-Y., Juengel, J. L., Ross, I. K., Lumsden, J. M., Lord, E. A., Dodds, K. G., Walling, G. A., McEwan, J. C., and O'Connell, A. R.: Highly prolific Booroola sheep have a mutation in the intracellular kinase domain of bone morphogenetic protein IB receptor (ALK-6) that is expressed in both oocytes and granulosa cells, Biol. Reprod., 64, 1225-1235, 2001.

Yan, C., Wang, P., DeMayo, J., DeMayo, F. J., Elvin, J. A., Carino, C., Prasad, S. V., Skinner, S. S., Dunbar, B. S., and Dube, J. L.: Synergistic roles of bone morphogenetic protein 15 and growth differentiation factor 9 in ovarian function, Mol. Endocrinol., 15, 854-866, 2001.

Zamani, P., Nadri, S., Saffaripour, R., Ahmadi, A., Dashti, F., and Abdoli, R.: A new mutation in exon 2 of the bone morphogenetic protein 15 gene is associated with increase in prolificacy of Mehraban and Lori sheep, Trop. Anim. Health Prod., 47, 855$860,2015$. 